\title{
Thinking Systemically-Thinking Politically: Building Strong Partnerships with Children and Families in the Context of Rising Inequality
}

\author{
Brid Featherstone ${ }^{*}$, Karen Broadhurst, and Kim Holt
}

Professor Brid Featherstone is Director of Social Work at the School of Political Science and Sociology, National University of Ireland, Galway, Republic of Ireland. Dr Karen Broadhurst is Senior Lecturer in Social Work and Social Science in the Department of Applied Social Science, Lancaster University, Lancaster, UK. Ms Kim Holt is Head of Division for Social Work and a Senior Lecturer in Social Work at the School of Social and International Studies, Bradford University, Bradford, UK. She is also a practising barrister.

*Correspondence to Professor B. Featherstone, School of Political Science and Sociology, National University of Ireland, Galway, Ireland. E-mail: Brigid.featherstone@nuigalway.ie

\begin{abstract}
Prompted by findings from the Munro Review of Child Protection, this paper provides a critical analysis of the combination of changes that appear to have undermined social workers' ability to develop strong partnerships with children and their families. Here, we engage with a number of now familiar lines of critique that have exposed the negative consequences of aspects of New Labour's modernisation agenda (such as excessive standardisation). However, we challenge our readers to think more broadly about the political foundations of the New Labour project and, in particular, to consider how neo-liberal policies have in the past and are likely in the future to lead to the intensification of inequalities, thus undermining effective family work. Efforts to deal with excessive rules and procedures, or the revision of performance targets, as suggested in the Munro Review, will not mitigate the corrosive effects of rising social inequality. If we are to think systemically, as Munro suggests, then we must consider the likely regressive impact of impending public sector and welfare cuts and challenge any moves to sideline family support and restrict social work to a narrow focus on child protection.
\end{abstract}

Keywords: Child protection, child welfare, family support, social policy

Accepted: May 2011 


\section{Introduction}

Helping children, families and adults who are in crisis or in difficult or dangerous situations to be safe, to cope and take control of their lives again requires exceptional professional judgment. Social workers have to be highly skilled in their interactions and must draw on a sound professional understanding of social work. They have to be able to do all of this while sustaining strong partnerships with the children or adults they are working with and their families: sometimes they will be the only people offering the stability and consistency that is badly needed (Social Work Task Force, 2009, quoted in Munro Review of Child Protection, 2010, p. 30).

The first report of the Munro Review of Child Protection (Part One: A Systems Analysis) endorsed key themes that emerged from the work carried out by the Social Work Taskforce as well as a range of critiques that emerged in the aftermath of the tragic death of baby Peter Connelly. In particular, the review by Munro confirmed concerns about the negative impact of inspection and performance management regimes on the priorities of frontline workers. Munro (2010, p. 7) described the excessive technical emphasis of recent reforms to social work - 'increasing rules, more detailed procedures and more use of ICT' that have reduced the time available for direct engagement with families. In a call to reclaim professional judgement, the review suggested that social workers' dependence on prescriptive rules should be replaced by 'best professional principles' and 'guided judgement' (Munro, 2010, p. 31). The emphasis on strong partnerships with children and families is most welcome, seeming to herald an important turning point.

However, we would argue that models of practice do not emerge or exist in a vacuum; they are intricately linked to political, economic and social projects. The models of practice that emerged under New Labour, therefore, need to be understood within the wider social and economic rationalities of that project. Munro asks us to think systemically and we agree. However, thinking systemically about improving children's safety and wellbeing must involve an analysis of the political commitments of successive governments to 'welfare' and, most importantly, to addressing inequalities. Indeed, we would suggest this is where the hopes and expectations of the 1989 Children Act, with respect to partnership working, first began to falter, given the advent of this act under the Thatcher Government.

In the second report of the Munro Review (Munro, 2011), direct reference is made to the tighter fiscal climate (Paragraph 5.4, p. 77) with the report concluding that these conditions coupled with 'major reform in all of the relevant public services... may make the ideal child protection system look further away' (Paragraph 6.7, p. 96). We concur with this conclusion and seek to further develop this analysis. In the current climate, without a clear understanding of how neo-liberal policies have led to the intensification of existing inequalities, efforts to improve practice through 
the many excellent recommendations emerging from the Munro Review will likely falter. Critical accounts that focus on this or that aspect of the modernisation agenda that developed primarily under New Labour offer rich detail that we would not want to dismiss, but systemic thinking must incorporate an understanding of a combination of changes: practical, technological but also political, that impact on the organisation and possibilities for effective partnerships with families.

The analysis offered in this article is informed by our involvement in a number of funded research projects in the last decades, a review of the literature and supplemented by illustrative observations from fieldwork currently being undertaken. ${ }^{1}$

\section{Policy contexts: neo-liberalism, inequality and market imperatives}

The notion of partnership that is implicit in the 1989 Children Act and explicit in a range of government guidance demanded that every effort be made to work in partnership with parents and children (Department of Health, 1989). Through effective partnership work, parents would be supported with the upbringing of their children to ensure their safety and wellbeing. However, a substantial body of evidence has documented the difficulties of achieving effective partnerships with families (Broadhurst and Holt, 2010).

It is important to note the context in which the Children Act was introduced-a context in which neo-liberalism was dominant with an associated growth in inequalities. Throughout the 1980s, sections of the population and, indeed, regions of the UK were essentially written off, child poverty rates soared and the gap between rich and poor grew wider. Thus, those attempting to enact the partnership ethos of the new legislation faced significant challenges. Policy frameworks set the parameters for social work practice and, under the Thatcher Government, many families needing help were turned away from services, as practitioners focused narrowly on child protection in the context of residualised welfare services and the sidelining of family support activities (Department of Health, 1995).

The widening of inequality was not accidental but must be understood in the context of the neo-liberal trajectory pursued by the Thatcher Government and the subsequent Major Government. As Harvey (2005) has argued, neo-liberalism can be understood as a project that seeks the restoration of class power by those worried by their loss of economic and political power during the era of welfare capitalism after the Second World War. He noted the turnaround in the share of national income going to top income earners in a range of countries between the late 1970s and 1999. 
Why does inequality matter so much? Epidemiologists Richard Wilkinson and Kate Pickett (2009) have brought together an array of evidence in their book, The Spirit Level: Why More Equal Societies Always do Better, to reach important conclusions. They have collected internationally comparable data on health and a range of social problems. They argue that there is a very strong link between ill health, social problems and inequality. Differences in average income between whole populations or countries do not seem to matter, but differences within those populations or countries matter very much.

Wilkinson and Pickett note strong findings from the data that levels of trust between members of the public are lower in countries where income differences are larger. For example, people trust each other most in the Scandinavian countries and the Netherlands and least in very unequal countries such as Portugal and the UK.

A linked insight from their work concerns how inequality within a society 'gets under the skin' of individuals, leaving them feeling unvalued and inferior. They note the work of the sociologist Thomas Scheff, who argued that shame was the social emotion. 'Shame and its opposite, pride, are rooted in the processes through which we internalize how we imagine others see us' (Wilkinson and Pickett, 2009, p. 41). Greater inequality heightens our anxieties because it increases the importance of social status.

Thus, it is crucial to locate social work and social care practices under the 1989 Children Act within a societal context in which the gap between rich and poor had grown much wider, and in which inequality was promoted as a necessary feature of development. If we accept Wilkinson and Pickett's analysis, then many people felt unworthy of respect and that their time and priorities were not valued. Thus, they, in turn, found it difficult to trust others. The failure to build strong partnerships and to develop family support practices and to re-focus practice away from suspicious forensic approaches as outlined in Messages from Research (Department of Health, 1995) must be considered in such a context. As Parton (1997) noted, the discussions around re-focusing that emerged in the wake of the publication of Messages from Research were not adequately located in an understanding of the enormous social and economic changes that had ensued under the Thatcher Government as well as the impact of successive inquiries into child deaths. Re-focusing was constructed as a voluntaristic project that required social workers simply to change how they worked and ignored why, in the contexts that they were in, their ways of working made sense (Featherstone, 2004).

With the advent of New Labour in 1997, a centre ground politics emerged that continued the central thrust of neo-liberalism but through the adoption of the social investment state sought to modernise many aspects of the supports available to families (via tax and income changes as well as services). Moreover, an array of services emerged in relation to early intervention and prevention. Labour's welfare reforms have been extensively evaluated 
(Hills et al., 2009). The official statistics show there were significant increases in employment rates and reductions in unemployment and child poverty. However, child poverty returned to an upward trend from 2004/ 05 and economic recession from 2008 reversed unemployment trends, although there is an argument that the welfare reforms introduced by New Labour helped ameliorate some of the impact of the recession especially on unemployment (see Churchill, 2011, p. 107).

In charting a 'new' approach to welfare, New Labour demanded a return on the investment in social protection-hence, for parents, the government made clear its intention to invest in human capital (largely parenting skills and employability), rather than simply income maintenance. In this context, parents (more often poor women) were no longer seen as welfare subjects in their own right, worthy of support, but simply as conduits for ensuring the welfare of their children through the taking on of parental responsibility (Featherstone, 2004).

As indicated, an array of services was introduced in order to promote early intervention and tied family support to an investment and control rationale (Featherstone, 2006). There seemed to be a difficulty with looking at families and relationships holistically and the identities of children and parents were disaggregated with children constructed as investments and parents, increasingly named as mothers and fathers, constructed in terms of carrying responsibilities. As Hall et al. (2010) described, because assessment technologies required a child-centric response, possibilities for addressing parents' needs in their own right were significantly constrained. A key development promoted by Every Child Matters was the division of services into separate services for children and adults (Frost and Parton, 2009). This organisational split (running through from central government to the point of service delivery) reflected an underlying tendency to conceive of relationships between children, their parents and wider family members as separate.

There was an abstract and disembodied approach to parenting increasingly constructed in terms of a set of techniques to be taught (reflected in and supported by features of the research and practice context explored further below) rather than understood in terms of relationships that operated across gender and generation. When the language of family and of family support did appear under the aegis of the Respect Agenda, the explanations of the problems and policy and practice proposals were very similar to ideas promoted by Sir Keith Joseph about the 'cycle of deprivation' in the early 1970s (Joseph, 1972). As Frost and Parton (2009, p. 165) noted, the emphasis seemed to shift from the earlier more universal emphases embodied by Sure Start towards a more muscular interventionist stance towards those who seemed 'hard to reach'. Partnerships with parents at a range of levels were constructed within a framework of conditionality (you behave and we will then give your rights, let you keep your children and so on) and the notion of time took on a central significance. A future- 
oriented approach to children obliged prioritising key periods of their lives. Parents were subject to time-limited injunctions to perform, learn how to be good parents and so on (Morris and Featherstone, 2010).

We now turn to a detailed analysis of selected methodologies that have been identified by Munro as centrally problematic to promoting the safety and well-being of children, but that require further analysis to uncover their political and ideological foundations. First, we discuss the impact of New Labour's appropriation of evidence-based policy making and associated targets and audit culture, in regard to the constructions of family (particularly 'good' parenting) that this apparatus embeds. Second, we consider new technologies of practice (networked computer, laptop, mobile phone, call centres) in the context of the broader 'distancing' effects of an increasingly conditional approach to welfare. Thus, we speak to familiar debates but offer a different critical analysis.

\section{Thinking systemically (politically) about performance and audit}

Under successive periods of the New Labour Government, a significant intensification of evidence-based policy making (EBPM) together with an associated culture of targets and audit occurred (Sanderson, 2002; Geyer and Rihani, 2010; Burton and van den Broek, 2008). These interlinked policy developments have been subjected to significant critique because excessive standardisation, emanating from New Labour's aspiration to control from the centre, has led to a number of unhelpful practice effects (Broadhurst et al., 2010b).

In Part One of the Munro Review, there was clear reference to the negative results of these policy developments, with inspection and audit described as skewing front line practice to the detriment of effective family work. However, what has been rather left out of critical debate is an analysis of notions of family that underpin this apparatus - notably constructs of 'good parenting'. It is important that the foundations of EBPM are examined in regard to familial ideology so that a fuller understanding of the skewing effects of policy can be seen.

New Labour's standardising agenda had much to do with efficiency in public services, but was also founded on a particular mandate for parents that demanded timely improvement and particular directions for change. The denigration of dependency led to short-termism in family support provision and required that parents perform against targets set in family support and/or child protection plans, sui generis. Local authorities were and are still required to provide performance data on the length of time that children are subject to child protection plans and this creates temporal imperatives for both worker and family caught up in a system in which help 
is conditional and time-limited (Morris and Featherstone, 2010). In this context, longer-term support is far harder to deliver given Ofsted's $a$ priori formulations of service episodes (annual performance statistics count the duration that children are subject to plans in terms of twelve and twenty-four-month intervals). Moreover, organisational time frames between planning and review now count more for families, given agency requirements to document service outcomes. For families, this may set an unrealistic pace for change, given the combination of difficulties that bring vulnerable families to the door of statutory services. In the course of fieldwork that we are currently completing, we have noted that practitioners refer to child protection episodes when providing a rationale for initiating care proceedings. That vulnerable families may simply require on-going support presents too much of a methodological challenge under services constrained by New Public Management and founded on political notions of self-governance and self-responsibility in parenting.

Family support, while still the operative word within statutory services, cognisant with the ethos of the 1989 Children Act, finds little resonance with frameworks that are shaped according to ideologically driven performance demands resulting in far less space for holistic, relationship-based practice. Practitioners have little choice but to pass on Ofsted's epistemological authority to parents given that their agency's success and indeed their own jobs are linked to staying within parameters set externally according to statistical averages. EBPM and the associated culture of targets and audit have seen the emergence of a more contractual approach (governance through paper) to family work. While we would not want to negate the importance of planning, all too often, parents are set 'targets' for behavioural change, but offered little by way of flexible, practical and emotional support to improve parenting capacity. Rather, as a practice manager described to us in regard to a mother whose children were about to become subject to care proceedings: 'she could wallpaper her house with the letters and documents we have sent her.' From our fieldwork experience, practitioners are clearly motivated to 'go the extra mile' for families, but find themselves constrained by an increasingly conditional and behaviourally focused approach to family work. These practice constraints mediate against partnership working-take, for example, the case of the re-referral indicator. To return to ask for help might be seen in other contexts as a sign of a quality service; however, for local authority social workers, too many re-referrals within a twelve-month period suggest inappropriate 'thresholds' or ineffective service provision.

It is not just temporal imperatives of statutory social work that appear to mediate against flexible, family work - there are further limitations arising from the former government's standardising agenda. New Labour's particular appropriation of EBPM favoured the 'off the shelf', branded, parenting programme such as 'Incredible Years', which focused narrowly on behavioural change (Broadhurst, 2009). While, at a rhetorical level, New 
Labour stressed the inter-connectedness of issues that impact on parenting capacity, accepting an association between socio-economic disadvantage and life chances, in practice targeted intervention focused more closely on tackling so-called 'poverty of ambition' or 'attainment' (Deacon, 2003). New Labour's ideological commitments to parenting programmes, in particular, have served to limit alternative forms of family support intervention. Thus, family support emerged as a far cry from the much heralded open access family centres that offered practical support, such as washing facilities, a hot dinner and childcare (Pithouse and Holland, 1999). This standardising effect is felt across a range of services, not just those offered by the local authority. Funding streams increasingly tied a range of agencies into programmes of behaviour change influenced by central government dictates (Broadhurst, 2009). Thus, as Bourdieu (2002) has described, workers now find themselves between a rock and a hard place'-trapped in overly rigid bureaucratic institutions. While workers might endeavour to work around constraints, excessive standardisation coupled with political ethos of welfare conditionality has delivered shortterm, less flexible methods for family work.

Currently, the UK faces something of a crisis in the number of care proceedings, with CAFCASS figures reporting some of the highest figures on record for care demand (CAFCASS, care statistics release, October 2010). Concerns about the number of applications for care proceedings are not new (Beckett, 2001), yet consistent messages derived from parents' perspectives that might suggest alternative directions for child protection and family support appear to have had very little policy impact. In Brophy's (2006) review of the literature as part of the national Care Proceedings Review, she noted that studies of parents' perspectives indicated the failure of services to meet parents' needs for respite, childcare, financial and other practical support. Here, we are reminded of the prescient observations by Penn and Gough (2002) in an article titled 'The price of a loaf of bread: Some conceptions of family support'. Often, the most valued form of support may indeed be the price of a loaf of bread or a lift to the hospital to see a sick child rather than a parenting programme! The intensification of an individualising neo-liberal discourse of welfare has served to obscure the social-structural difficulties that many vulnerable families endure. Influenced by New Labour's particular version of evidenced-based practice, family support, delivered through time-limited and standardised programmes of parent education, is based on a reductive analysis of needs, conflating multiple vulnerabilities of social networks, environmental resources, parenting capacity and health and well-being to, simply, skills deficits.

Thus, in order to reclaim strong partnerships with families, it is not just 'red tape' or target and audit that require reconsideration. Indeed, a much more fundamental review of the legacy of New Labour's particular appropriation of EBPM in regard to political constructions of families is required. The 'best professional principles' and 'guided judgements' to 
which Munro refers in her first report may be easier to enact through the scaling down of the performance framework and the resurrection of professional supervision. However, it is likely that such solutions will be partial if the fundamental context for welfare delivery is not conducive to providing compensatory family support based on a holistic view of the needs of children and their parents.

\section{Thinking systemically about digitisation and distance}

Communication in public services has been fundamentally transformed in the past couple of decades, through what is variously described as digitisation/e-social work. In common with broader societal changes in patterns of communication, networked computer systems, laptops, mobile phones, SMS messaging and centralised call centres have significantly changed patterns of social interaction (Tregeagle and Darcy, 2008). Of particular concern for social work, and flagged as a central issue in the work of the Munro Review, is that increased information demands, when they coalesce with the 'turn to the computer', have taken social workers away from face-to-face practice. However, we would again challenge our readers to think more broadly about how it is that remote ways of working appear to have gained acceptance within spheres of social work practice.

There is no doubt that new forms of 'objectifying practices' (i.e. practices and technologies that construct and record the subject of welfare) have emerged in a range of public services (Mort et al., 2003; Mort and Smith, 2009). In social work, new objectifying practices are particularly evident in approaches to assessment that rely, increasingly, on the assembly of information gathered at a distance. Information, such as the ready metrics of school attendance statistics or health data, can circulate between an increasingly complex, e-network of multi-agency professionals, who have varying levels of 'direct' contact with families. This has led commentators to question the locus of professional decision making and to claim that practitioners now base their assessments on different kinds of knowledge about families (Parton, 2008). There is no doubt that technology can mobilise and transform data about families; however, we should avoid an assumption of technological determinism and seek to locate technology's impact within the context of broader changes within welfare delivery. Arguably, the distancing effect of the computer reflects not just technological shifts, but also shifts in welfare retrenchment that have created a greater divide between welfare provider and welfare recipient.

A number of commentators have discussed the marginalising effect of increasing conditionality within welfare policy. If welfare support is increasingly selective and targeted, this can lead to greater differences between those providing and receiving services. As described above, the importance of social status and thus difference is more pronounced in societies that are 
more unequal. Polarisation also creates physical divides, with users of social work services becoming concentrated in the poorest neighbourhoods.

Thus, we can account for the shift in priority from the direct work with families, to administrative practices, for example, through images of the practitioner tethered to the computer workstation, but the shift away from face-to-face practice needs also to be understood in terms of a broader tendency within welfare provision to distance the service user. During the past two decades, statutory social work with children and families appears to have increasingly drawn back from direct contactindeed, physical barriers have been erected in the form of far greater levels of security that stand between service provider and service user. Moreover, family work often now takes place in organisational spaces away from the family home-such as contact centres. If we chart the typical pathway to statutory services for the help-seeker, they face multilayered obstacles to access. First, initial contact with local authority children's social care is most likely to be mediated through centralised call or customer centres that offer a standardised impersonal response. Second, service users must hold an 'entry ticket' to services - that is, they must satisfy eligibility criteria in order to reach the threshold for help. Third, help that is offered is more focused, planned and directive and will be delivered by a series of workers located in 'compartments' of practice that are likely to be more task than relationship-focused. This combination of layers creates a much more distanced and less penetrable space for helpseekers as numerous near misses and child deaths testify (e.g. Baby H, Redbridge Local Safeguarding Children Board, 2008). Moreover, at each point in the system, information is collected about families, but this information is not simply neutral or storable; rather, it constructs particular accounts of families that are increasingly risk rather than needs-focused. These changes are technological and reflect broader changes in societal communication patterns, but they coalesce with a long-standing ideological shift towards selectivism in welfare policy that serves to keep people out of services, unless they satisfy narrow risk-based criteria.

The problem is that distance compounds itself. Where issues of trust combined with statutory targets limit home visiting to simply monitoring the family home (Broadhurst et al., 2010b), then the conditions for trust formation are unlikely to be fostered. Within the social work literature, there is much reference to quality engagement with service users; however, co-presence, which many have argued is essential to the formation of relationships, is increasingly squeezed out of the important space of statutory practice. As Urry (2003) describes in his analysis of changes in forms of communication, co-present interaction is fundamental to social life because eye contact appears to enable and stabilise intimacy and trust. We would argue that mutual attentiveness is very important to the development of strong partnerships with families and that, currently, societal and organisational barriers stand in the way of this. Given the current 
organisation of practice in statutory settings, it is of little wonder that lack of parental engagement is so frequently cited in the context of care proceedings. Moreover, judgements of Solomon (Taylor et al., 2008) are arguably more easily taken when working with remote(r) representations of families. In this context, current figures in relation to care proceedings become more explicable.

In terms of new spatialities of relationships of welfare under conditions of neo-liberalism, it is also important to consider the impact of 'out-sourcing' of key aspects of service design and delivery. Herein lies a new set of distancing effects ushered in by a market approach to welfare coupled with key technological changes as described. A number of commentators have flagged problems of design in the creation of technological tools for practice-specifically the Integrated Children's System (White et al., 2010; Broadhurst et al., 2010b; Wastell, 2010). Poor design, with overly rigid, centrally driven compliance regulations for ICS (now relaxed), has created untold problems for practitioners attempting to narrate a detailed account of the circumstances of parents and children (Peckover et al., 2008). Perhaps even more important, however, is that the failure of architects of ICS to focus on retrieval has meant that the outputs of ICS are not family-friendly (White et al., 2010; Broadhurst et al., 2010a). That a case history is difficult to retrieve has clear implications for the practitioner who has great difficulty trying to construct a history, but equally for the service user, trying to make sense of his/her own history. Here, the case of children and young people in care, accessing records in order to make sense of personal histories, is a poignant example. However, there may be more to this than simply design problems. Indeed, given the design capability of transnational software corporations, issues bound up with corporate responsibility may also be causal.

The private/for profit sector plays an increasing role in the delivery and management of public services (Sklair and Miller, 2010). New Labour embraced the private sector as part of its modernisation agenda, but, in terms of welfare policy, this has created networks of dispersed actorswhere motives towards the service user are not clear (Mooney and Law, 2007). Corporate profit-oriented organisations operate, at some distance, from the world of the service user. Without direct engagement with the vulnerabilities of families, there may be little emotional challenge to the imperative of profit for the commercial provider. New Labour's modernisation agenda pushed local authorities into relationships of dependency with commercial profit-oriented software companies, the impact of which is under-researched, in terms of either costs or broader humanistic concerns. During our fieldwork, managers have frequently described problems of revising systems, ill-suited for the task of social work and resulting in huge costs for individual agencies. The standard process of an initial sign-up to an ICS product delivered the cash flow for commercial providers, but did not necessarily provide the incentive for quality, on-going system 
revision and support. Here, we would not want to advocate a 'return to paper' - rather caution in regard to an emerging evangelical belief in the private sector to drive up quality in the context of current moves to further commercialise social work.

\section{An emerging agenda from the Coalition government?}

During the early days of the Coalition Government, there were some promising statements from Tim Loughton (Children's Minister) in regard to the important role that social workers play in the protection of children. The central thrust of the Coalition's vision for the improvement of social work is to strengthen front line practice, through a reduction in the bureaucratic burden on practitioners and to retain experienced workers. The review of child protection stimulated by the Coalition is also welcome, as is the continuation, at least at a policy level, of the New Labour interest in early intervention (see, e.g. Allen, 2011). However, this must be set alongside the emerging evidence of cuts such as those to Sure Start programmes, Book Start programmes for toddlers and financial cuts to new mothers. As Toynbee (2011) notes, 'Austerity babies born this month lose $£ 1,783$ in their first year'. Widespread cuts to youth services will also impact on vulnerable young people, who already struggle to access services (Rees et al., 2010).

If we are to think systemically, then we must consider the impact of public sector and welfare cuts upon social work and the ability of social work to promote the safety and well-being of children. In particular, the issue of rising inequality, much discussed towards the end of the former Labour Government's period in office, is now rapidly slipping off the central government agenda. As the axe falls on a range of public services that includes a broad range of child welfare services, there is a worrying silence about family support in a broad sense and the consequences of inequality for families and their ability to care.

Indeed, the Coalition Government has announced that public services will no longer be required to comply with the 'socio-economic duty'that is, the duty to scrutinise every new policy in regard to its impact on poverty. As part of the Equalities Act, resulting from the sustained academic analysis of the National Equalities Panel, the decision to remove the socio-economic duty is on the basis that it is (in the words of Theresa May, current Equalities Minister) 'political correctness and social engineering'. However, we are less convinced than May that the powers of the market will deliver a more equal society. Here, the response to this recent move from Alison Garnham, chief executive of the Child Poverty Action Group, is important: 
This is an extraordinary decision that axes future fairness in one fell swoop .... Far from being a box ticking exercise, the duty would have given power to the powerless, making sure the voices of the most disadvantaged have a say in how government at all levels makes decisions that affect their lives (reported in Children and Young People Now, 17 November 2010).

The announcement as part of the October 2010 Comprehensive Spending Review (CSR) of a shift away from the universal child benefit benchmarks a new era of selectivism in regard to state support to families. While seen as part and parcel of a 'necessary' curtailment of public spending given the current fiscal crisis, this move is profoundly ideological. Drawing on the analysis of the overall distributional impact of the CSR by the Institute of Fiscal Studies, early analysis indicates that the impact of the CSR will be regressive (IFS, 2010). That is, the overall impact of combined tax and benefit measures will reduce the incomes of lower-income households by more than that of higher-income households, with the exception of the richest 2 per cent of the population.

Since the Thatcher Government, we have witnessed something of a crossparty consensus in regard to reduced political support for the welfare state. This reduced commitment has been manifest in increasingly, selective, means-tested and conditional support to families. While politicians charge the populace to accept this on the basis of economic demands, if we consider the impact of increasing selectivity for families and society, herein lie costs that are less well documented. Bauman succinctly describes the impact of selectivist welfare policies in terms of the divisions created in society:

Confine the provisions of services to a means test and the community is immediately split into those who give without getting anything in exchange, and those who get without giving (Bauman, 2005, p. 50).

Osborne's public-spending cuts will hit hard those with the least to give and finds legitimation through appealing to an increasingly self-conscious and self-righteous majority who 'give without getting'. The outcome of an increasingly selectivist approach to state support to families is to enable government to more easily persuade the populace that a more residual and punitive approach to welfare is legitimate.

Returning to social work - widespread populist support from those who 'give without getting' for the further residualisation of welfare does not bode well for the profession. There is no doubt that a narrow set of activities that cohere around the 'protection of children' will survive, but the prospects for a broader family support agenda that locates protection within a wider understanding of the support and welfare needs of families looks more precarious. 


\section{Conclusion}

Social workers, operating under conditions of intense job insecurity and with limited resources to offer families, may find welcome acknowledgement of the impact of excessive bureaucracy under the Coalition Government but we would contend that the cumulative impact of austerity measures upon the poor will undermine the possibilities for effective social work practice, including the building of strong partnerships with families. A far more challenging climate for practice is emerging, as services contract and 'families in the most deprived districts are being hammered over and over again by one Coalition policy after another' (Toynbee, 2010).

In a context of rising inequalities, the corrosion of trust and the internalisation of shame and social inferiority are of particular concern not only in terms of consequences for the wider social fabric, but also in terms of how such features get played out in everyday practice encounters, particularly where the stakes are very high (e.g. where issues around the protection of children are on the agenda).

We would thus argue that many aspects of the Munro Review are most welcome, but, without a clear understanding of the likely impact of the wider political context within which recommendations are located, its analysis and recommendations for practice may be undermined. Moreover, it is possible that its recommendations could legitimate future attacks upon 'newly freed up' social workers by a Coalition Government seeking to obscure the part placed by their own policies in the difficulties that will emerge in relation to building strong partnerships with families.

1. Because of word constraints, it is not possible to detail this fieldwork in this paper. We use some examples as illustrative in this particular context but a full account of the fieldwork is forthcoming.

\section{References}

Allen, G. (2011) 'Early intervention: The next steps', available online at www.dwp.gov. $u k / d o c s /$ early-intervention-next-steps.pdf.

Bauman, Z. (2005) Work Consumerism and the New Poor, Maidenhead, Berkshire, Open University Press.

Beckett, C. (2001) 'The great care proceedings explosion', British Journal of Social Work, 31(3), pp. 493-501.

Bourdieu, P. (2002) 'Social space and symbolic power', in M. Haugaard (ed.), Power: A Reader, Manchester, Manchester University Press.

Broadhurst, K. (2009) 'Supporting parents under New Labour: How does every parent matter?', in K. Broadhurst, G. Grover and J. Jamieson (eds), Critical Perspectives on Safeguarding Children, Oxford, Wiley-Blackwell. 
Broadhurst, K. and Holt, K. E. (2010) 'Partnership and the limits of procedure: Prospects for relationships between parents and professionals under the New Public Law Outline', Child and Family Social Work, 15(1), pp. 97-106.

Broadhurst, K., Hall, C., Wastell, D., White, S. and Pithouse, A. (2010a) 'Risk, instrumentalism and the humane project in social work: Identifying the informal logics of risk management in children's statutory services', British Journal of Social Work, 40(4), p. 1046-64.

Broadhurst, K., Wastell, D., White, S., Hall, C., Peckover, S., Thompson, K., Pithouse, A. and Davey, D. (2010b) 'Performing "initial assessment" identifying the latent conditions for error at the front-door of local authority children's services', British Journal of Social Work, 40(2), pp. 352-70.

Brophy, J. (2006) Care Proceedings under the Children Act 1989: A Research Review, Research Series 06, London, Department for Constitutional Affairs.

Burton, J. and van den Broek, D. (2008) 'Accountable and countable: Information management systems and the bureaucratization of social work', British Journal of Social Work, 22(4), p. 601-13.

Churchill, H. (2011) Parental Rights and Responsibilities, Bristol, Policy Press.

Deacon, A. (2003) 'Levelling the playing field: Activating the players, New Labour and the "cycle of disadvantage", Policy and Politics, 31(2), pp. 123-37.

Department of Health (1989) The Care of Children: Principles and Practice in Regulations and Guidance, London, Her Majesty's Stationery Office.

Department of Health (1995) Child Protection: Messages from Research, London, The Stationery Office.

Featherstone, B. (2004) Family Life and Family Support: A Feminist Analysis, Basingstoke, Palgrave, Macmillan.

Featherstone, B. (2006) 'Why gender matters for child welfare and protection', Critical Social Policy, 26(2), p. 294-319.

Frost, N. and Parton, N. (2009) Understanding Children's Social Care, London, Sage.

Geyer, R. and Rihani, S. (2010) Complexity and Public Policy: A New Approach to 21st Century Politics, Policy and Society, London, Routledge.

Hall, C., Parton, N., Peckover, S. and White, S. (2010) 'Child-centric ICTs and the fragmentation of child welfare practice', Journal of Social Policy, 39(3), pp. 393-413.

Harvey, D. (2005) A Short History of Neoliberalism, Oxford, Oxford University Press.

Hills, J., Sefton, T. and Stewart, K. (eds) (2009) Towards a More Equal Society? Poverty, Inequality and Policy since 1997, Bristol, Policy Press.

Institute for Fiscal Studies (IFS) (2010) Distributional Analysis of Tax and Benefits, available online at www.ifs.org.uk/publications/5313.

Joseph, K. (1972) 'The cycle of deprivation', speech to Conference of Pre-School Playgroups Association, Westminster, 29 February.

Mooney, G. and Law, A. (eds) (2007) New Labour/Hard Labour? Restructuring and Resistance in the Welfare Industry, Bristol, Policy Press.

Morris, K. and Featherstone, B. (2010) 'Investing in children, regulating parents, thinking family: A decade of tensions and contradictions', Social Policy and Society, 9(4), p. 557-66.

Mort, M. and Smith, A. (2009) 'Beyond information: Intimate relations in sociotechnical practice', Sociology, 43(2), pp. 215-31.

Mort, M., May, C. and Williams, T. (2003) 'Remote doctors and absent patients: Acting at a distance in telemedicine', Science, Technology \& Human Values, 28(2), pp. 274-95. 
Munro, E. (2010) The Munro Review of Child Protection: Part One: A Systems Analysis, available online at www.education.gov.uk/munroreview/downloads/TheMunro ReviewofChildProtection-Part\%20one.pdf.

Munro, E. (2011) The Munro Review of Child Protection: Interim Report: The Child's Journey, available online at www.education.gov.uk/munroreview/downloads/ Munrointerimreport.pdf.

Parton, N. (1997) 'Introduction', in N. Parton (ed.), Child Protection and Family Support, London, Routledge.

Parton, N. (2008) 'Changes in the form of knowledge in social work: From the "social" to the "informational"?', British Journal of Social Work, 38(2), pp. 275-7.

Peckover, S., White, S. and Hall, C. (2008) 'Making and managing electronic children: Eassessment in child welfare', Information, Communication and Society, 11(3), pp. 275-94.

Penn, H. and Gough, D. (2002) 'The price of a loaf of bread: some conceptions of family support', Children and Society, 16(1), pp. 17-32.

Pithouse, A. and Holland, S. (1999) 'Open access family centres and their users: positive results, some doubts and new departments', Children and Society, 13, pp. 167-178.

Redbridge Local Safeguarding Children Board (2008) 'Child H: A Serious Case Review: Executive Summary', available online at www.redbridge.gov.uk/cms/benefits_ care_and_health/children_and_families/protecting_and_safeguarding/safeguarding_ children_board/publications_policies_and_pro/serious_case_reviews_-_executi. aspx.

Rees, G., Gorin, S., Jobe, A., Stein, M., Medforth, R. and Goswami, H. (2010) Safeguarding Young People: Responding to Young People aged 11 to 17 Who Are Maltreated, London, The Children's Society.

Sanderson, I. (2002) 'Evaluation, policy learning and evidence-based policy making', Public Policy and Administration, 80(1), p. 1-22.

Sklair, L. and Miller, D. (2010) 'Capitalist globalization, corporate social responsibility and social policy', Critical Social Policy, 30(4), pp. 472-95.

Social Work Task Force (2009) 'Building a safe and confident future: Implementing the recommendations of the Social Work Task Force', availble online at www.education. gov.uk/swrb/documents.shtml.

Taylor, H., Beckett, C. and McKeigue, B. (2008) 'Judgments of Solomon: Anxieties and defences of social workers involved in care proceedings', Child and Family Social Work, 13(1), p. 23-31.

Toynbee, P. (2010) 'How to turn 60,000 students into unqualified drop-outs', The Guardian, 20 November.

Toynbee, P. (2011) 'David Cameron's well-oiled winning machine is now a car crash', The Guardian, 8 April.

Tregeagle, S. and Darcy, M. (2008) 'Child welfare and information and communication technology: Today's challenge', British Journal of Social Work, 38(8), pp. 1481-98.

Urry, J. (2003) 'Social networks, travel and talk', British Journal of Sociology, 54(2), p. $55-175$.

Wastell, D. (2010) 'Managing as designing: "Opportunity knocks” for the IS field?', European Journal of Information Systems, 19, p. 422-31.

White, S., Wastell, D., Broadhurst, K. and Hall, C. (2010) 'When policy o'erleaps itself: The "tragic tale" of the Integrated Children's System', Critical Social Policy, 30, p. $405-29$.

Wilkinson, R. and Pickett, K. (2009) The Spirit Level: Why More Equal Societies Always Do Better, London, Allen Lane. 